\title{
Molasses, Nitrogen Fixation and Land Reclamation
}

$\mathrm{I}^{\mathrm{N}}$ $\mathrm{N}$ his presidential address to the United Provinces Academy of Sciences, India, on December 19, 1935, Prof. N. R. Dhar gave a general account of the work carried out by himself and his collaborators on nitrogen transformations in soil. Prof. Dhar leads the school of thought which believes that nitrification in soils and nitrogen fixation from the atmosphere are, especially in the tropics, photochemical at least as much as bacterial actions. Prof. Dhar has produced strong evidence in support of his theories, and the question appears now to have reached the stage at which the protagonists of bacterial and photochemical nitrification respectively are unwilling to admit any evidence which might shatter their beliefs.

Meanwhile, other soil workers will be wise to keep an open mind on the matter, for the philosophical implications of recognising that light plays a part in soils analogous to photosynthesis in the vegetable kingdom are at least as important as the practical possibilities of utilising that knowledge for the enrichment of the soil. Given sufficient facts, their practical application does not necessarily depend on their correct interpretation. The practical facts of Prof. Dhar's researches are that Indian soils are generally deficient in nitrogen, that more than half a million tons of molasses from the sugar industry are annually wasted in India, and that the application of molasses to the soil can double and may treble the soil nitrogen content, with a consequent large increase in crop yield.

Molasses contains about 70 per cent of carbohydrates and small quantities of nitrogen, phosphorus, potash, etc., these quantities, however, being much too small to account for the observed manurial effect. According to Prof. Dhar, the energy set free in the oxidation of the sugars in molasses is utilised, either bacterially or photochemically, in promoting nitrogen fixation and nitrification. Whatever the nature of the process, Dhar has produced indisputable evidence of increases in available soil nitrogen and crop yields following the application of molasses. Under temperate conditions, the converse result would be expected, as it is well known that the addition of carbohydrate-rich material to soil tends to reduce the amount of nitrogen available to plants, the nitrogen becoming fixed as microbial protoplasm or as humus. An essential difference, however, between temperate and tropical soil requirements is that, whereas in temperate regions the limiting factor to crop growth is often the slowness, in the tropics it is the rapidity with which soil nitrogen is made available to plants, soluble nitrates being formed and leached from the soil before they can be absorbed by the crop. The general effect of molasses on the soil should be the same everywhere, but only in the tropics will its 'braking' effect on the mobilisation of soil nitrogen be a positive advantage to the cultivator, and only in the tropics will its stimulation of atmospheric nitrogen fixation, whether bacterial or photochemical, be appreciable, since temperate regions lack the heat necessary for bacterial and the light for photochemical stimulation.

For these reasons, the potentialities of carbohydrate manuring - of which molasses manuring is an example-have perhaps been overlooked by agriculturists. If Prof. Dhar can substantiate his claims, he may effect a revolution in agriculture in India, where the supply of the ordinary organic manures is far below the demand. Prof. Dhar suggests that a most valuable use can be made of molasses in reclaiming alkaline land. The acids produced in the decomposition of molasses neutralise the alkalis, and at the same time and contrary to experience when land is reclaimed with gypsum or sulphur, soil nitrogen is increased. A period of about four years is usually necessary to reclaim alkali land with gypsum, whereas with molasses applied at a rate of 30-40 tons per acre, good crops can be grown within six months. It is not stated whether such reclamations have been found permanent-in view of the oxidisability of the neutralising acids, this is open to doubt but the method obviously merits further study. There are four million acres of in. fertile alkali land in India, and irrigation practices are increasing the area. The economic reclamation of these lands is one of the country's greatest agricultural problems, to the solution of which Prof. Dhar's work is pointing the way.

\section{The Prehistoric Society}

$\mathrm{W}^{1}$ ITH the publication of its Proceedings* for 1935, the Prehistoric Society, formerly known as the Prehistoric Society of East Anglia, completes the first year of its existence under the new style and organisation. The change will necessarily bring some broadening of outlook ; but those who have followed with close attention the work of the Society under its old style, especially in recent years, are well aware that the change is one in form rather than substance. From the time of its first formation in 1908 the

- Proceedings of the Prehistoric Society for 1935 (Proceedings of the Prehistoric Society of East Anglia, 1908-1935). Edited by Dr. Grahame Clark. Pp. $166+15$ plates. (Cambridge: University Museum of Archæology and Ethnology.) $£ 1$.
Prehistoric Society of East Anglia, though strong in its local membership, reaped the advantage of its geographical position. It had the strategic advantage that many of its local discoveries and local problems were of more than local interest; they were also of the first importance in the discussion of some of the most significant of the questions relating to the antiquity of man and prehistoric archæology at large. A glance through the later volumes of the Proceedings will show that the proportion of attention given to these larger questions and the tendency to view local evidence in the light of its bearing on the broader issues had steadily increased, until the Society, so 
far as its proceedings were concerned, had earned the right to be regarded as a national rather than a local body. That fact is recognised in the change of title. On the other hand, the strength gained from local interest will be preserved by an organisation of local groups under honorary secretaries, which will focus interest in specific local areas.

Thanks very largely to the activities of Mr. J. Reid Moir, the Prehistoric Society has never feared the difficulties which beset the pioneer in archæological investigation; and if we may judge by the contents of the first volume of its Proceedings, the same policy will commend itself to the Society in its revised form. It will offer a free field for open discussion. This at least is the inference to be drawn from the tone of the first presidential address by Prof. V. Gordon Childe on "Changing Methods and Aims in Archaeology". Pointing out that the remarkable strides in discovery of prehistoric archæology during the last ten years call for a complete reconsideration of the position in prehistoric studies, he focuses a variety of 'discontents' expressed in various quarters, and boldly accepts their implication of the necessity for certain fundamental changes of nomenclature, point of view and method. For example, while he holds that chronology is the essential of prehistory, as it is of history, the old chronological classification of 'ages'-stone, bronze, iron-can no longer be regarded as bearing any precise significance, owing to the wide distribution in time as well as in space to which it is now recognised these terms are applicable as cultural designations. On the other hand, as he himself has already suggested, the various 'ages' do express phases in economic development, which have their place in a temporal relation, thus becoming even more significant when viewed in the light of Prof. Childe's reference to the present aim of archæology, which centres not so much on the intrinsic interest of the objects recovered as in the reconstruction of the culture of which they are an indication.

Prof. Childe dismisses in like vein the familiar chronological classification in a sequence of cultures based on the archæological finds of France, which no longer applies in the world-wide view of prehistoric problems which must now be taken. But in dealing with this and other concepts hitherto generally accepted, his criticism-a constructive criticism be it said is that the implication of the emphasis now laid on culture must be accepted to the full. It is no longer the period, but the culture which is the object of investigation. The chronological problem is to be solved through the relation in space and time of the various distinguishable cultures inter se.

Of the varied communications which follow the presidential address a bare mention of a few must suffice. Mr. G. A. Holleyman and Dr. E. Cecil Curwen describe their investigation of bronze age lynchet settlements on Plumpton Plain, Sussex. This produced some interesting pottery which is described by Mr. C. F. C. Hawkes. The pottery confirms and emphasises the distinction in date between site $A$, which belongs to the earlier Late Bronze Age from about 1000 B.C., and site $B$, which cannot be dated before 750 B.c. and covers the transition to the Early Iron Age centring approximately on 500 B.C. Mr. Henry Bury provides a welcome discussion of the Farnham terraces and their sequence and Dr. Grahame Clark furnishes an equally opportune survey of the prehistory of the Isle of Man.

The recent discussion, at the Norwich meeting of the British Association, of the antiquity of man in
East Anglia, gives a special interest to papers by Mr. Reid Moir on the Darmsden flint implements and a description of three Combe Capelle hand-axes from Norfolk; and a similar interest in a different context is attached, in view of recent discoveries in the county of Lincoln, to three papers dealing with long barrows-a description of the Therfield Heath Long Barrow, Royston, by Mr. C. W. Phillips, a discussion of a possible pedigree of long barrows and chambered cairns by Mr. W. J. Hemp, which is both suggestive and to some degree provocative, and a note on the relative chronology of English long barrows by Mr. Stuart Piggott. Mrs. Jacquetta Hawkes adds to her previous contributions to consideration of the place of origin of the Windmill Hill culture and advances her views a stage further.

A valuable feature of the miscellaneous items which complete the volume is a survey of results in the field in Great Britain and Ireland during 1935. Mention must also be made of a valuable résumé of recent work in Russia by Prof. Gordon Childe.

\section{Educational Topics and Events}

Cambridat-The following have been approved for the degree of Sc.D. : W. N. Bailey, of Trinity College, C. G. Darwin, Master of Christ's College, J. O. Irwin, of Christ's College.

At King's College, Dr. D. Purdie has been elected into a fellowship. Dr. Purdie was placed in the first class of the Natural Sciences Tripos, Part II, in 1932, and was elected to a Charles Kingsley Bye-Fellowship at Magdalene College in 1934.

Edinburgh.--Prof. W. H. McMillan, professor of mining in University College, Nottingham, has been appointed to the James A. Hood chair of mining in the Heriot-Watt College.

London.--Prof. A. K. Henry has been appointed as from March 1 to the University readership in surgery tenable at the British Postgraduate Medical School. Since 1925 he has been professor of clinical surgery in the Medical School, Cairo, and director of the Surgical Unit, Kasr el Aini Hospital, Cairo.

Loughborough CoLLEGE has been noted for many years as the sponsor of a combined theoretical and practical training system, essentially its own, which should constitute a good preparation for the administrative side of engineering. It has now extended this to include aeronautical engineering, and offers a course that should appeal to a type of man not very largely catered for at the present. The combined lectures, workshop, and aerodrome practice, constitute a four-year course leading to the Colloge diploma and the Air Ministry's ground engineer's licences. A fifth year qualifies for an honours diploms, and covers the syllabus of the examinations of the Royal Aeronautical Society. The instruction com. prises lectures and laboratory work, sandwiched with work in the production engineering workshops, on alternate weeks. The training is general during the first two years, but in the third and fourth year the practical work is entirely aeronautical, including aircraft rigging, maintenance, sheet metal work, engine repairs and testing. Flying instruction is also 